\title{
Housing Humidity Units
}

National Cancer Institute

\section{Source}

National Cancer Institute. Housing Humidity Units. NCI Thesaurus. Code C90396.

The units of measure that are used to express the humidity of a residential environment. 